\title{
Administratief Tribunaal van de Internationale Arbeidsorganisatie dringt zorgplicht op aan Internationaal Strafhof: werkneemsters van het Strafhof mogen flexibel werken om borstvoeding te kunnen geven
}

\author{
ILOAT 28 juni 2017, nr. 3861 (A.L.G./International Criminal \\ Court)
}

P. Foubert \& F. De Cock

\section{Inleiding}

De rechtspraak van het Administratief Tribunaal van de Internationale Arbeidsorganisatie (ILOAT; hierna: het Tribunaal') krijgt vaak niet de aandacht die ze verdient. Nochtans speelt dit Tribunaal een belangrijke rol. Het is het rechtsprekend orgaan voor tal van werknemers bij internationale organisaties en vult de arbeidsvoorwaarden bij deze organisaties aan op plaatsen waar zich een juridisch vacuüm manifesteert. ${ }^{1}$

De steeds verder schrijdende globalisering heeft tot gevolg dat internationale samenwerking aan belang wint. In tal van domeinen kunnen doelstellingen immers niet meer gehaald worden zonder grensoverschrijdende samenwerking. ${ }^{2}$ Bij wijze van voorbeeld kan verwezen worden naar telecommunicatie (International Telecommunications Union), klimaatbeheersing (World Meteorological Organization), landbouwontwikkeling (Food and Agriculture Organization, Crop Trust), handel (World Trade Organization, European Free Trade Association), patenten en intellectuele eigendom (European Patent Organisation), gezondheid (World Health Organization), criminaliteitsbestrijding (Interpol) en de berechting van oorlogsmisdaden (International Criminal Court).

Om hun taken naar behoren te kunnen uitoefenen beschikken deze internationale organisaties over verregaande immuniteiten en privileges, die gelden als hoekstenen van het internationale recht. ${ }^{3}$ Deze organisaties moeten immers in

1 Het Administratief Tribunaal van de Internationale Arbeidsorganisatie is bevoegd om over (veelal arbeidsrechtelijke) disputen van een zestigtal aangesloten internationale organisaties te oordelen.

2 Voor een uitgebreide uiteenzetting hierover, zie E. Kwakwa, Globalization and International Organizations, New York: Routledge 2016, p. 512.

3 Zie A. Reinisch, The Privileges and Immunities of International Organizations in Domestic Courts, Oxford: University Press 2013, p. 376. 
totale onafhankelijkheid hun taken en bevoegdheden kunnen uitvoeren. ${ }^{4}$ Daartoe zullen het oprichtingsverdrag en het zetelakkoord in principe de immuniteit van rechtsmacht en uitvoering bevatten. Dit houdt in dat de organisatie in beginsel niet kan worden gedagvaard. Komt het in uitzonderlijke gevallen toch tot een uitspraak, dan kan deze niet worden uitgevoerd.

Zelfs indien een expliciete vermelding zou ontbreken, dan nog wordt, althans wat Nederland betreft, aangenomen dat zulke verregaande immuniteit uit het ongeschreven volkenrecht voortvloeit. ${ }^{5}$ In België kwam het Hof van Cassatie echter tot een ander besluit: in afwezigheid van een verdrag geniet de internationale organisatie geen immuniteit. ${ }^{6}$ Aangezien er quasi altijd een verdrag voorhanden is, lijkt deze vraag op het eerste gezicht misschien eerder theoretisch van aard. ${ }^{7}$ Nochtans leiden de zware institutionele structuren in België ertoe dat de goedkeuring van verdragen niet steeds even vlot verloopt. Daardoor kan deze problematiek ook praktische consequenties hebben. ${ }^{8}$ De immuniteit wordt aldus niet in alle rechtstelsels op dezelfde manier benaderd en is bovendien ook nog eens afhankelijk van de doorwerking van het internationaal recht in de nationale rechtsorde. ${ }^{9}$ Vervolgens bestaat er ook onenigheid over hoe ver deze immuniteit precies gaat. ${ }^{10}$ Artikel 5 van het zetelakkoord tussen het Internationaal Strafhof en gastland Nederland meldt: "The Court shall enjoy, in the territory of the host State, such privileges, immunities and facilities as are necessary for the fulfilment of its purposes.' Deze formulering zou een functionele immuniteit impliceren, aangezien de reikwijdte begrensd wordt door hetgeen nodig is om het doel van de organisatie te vervullen. Toch moet opgemerkt worden dat het zetelakkoord ook stelt: 'The Court, its funds, assets and other property, wherever located and by whomsoever held, shall enjoy immunity from every form of legal process (...). Funds, assets and other property of the Court, wherever located and by whomsoever held, shall be immune from search, seizure, requisition, confiscation, expropriation and any other form of interference, whether by executive, administrative,

4 J. Cogan, I. Hurd \& I. Johnstone, The Oxford Handbook of International Organizations, Oxford: University Press 2016, p. 1053 e.v; N. White, The Law of International Organisations, Manchester: University Press 2005, p. 42; P.H.F. Becker, The Legal Position of Intergovernmental Organizations: a Functional Necessity Analysis of the Legal Status and Immunities, Dordrecht: Martinus Nijhoff 1994, p. 99.

5 Voor een grondige analyse van de immuniteiten die internationale organisaties in Nederland genieten, zie T. Henquet, International Organisations in The Netherlands: immunity from jurisdiction of the Dutch courts, Neth. Int. Law Rev. 2015, 57, p. 267-301.

6 Cass. 12 maart 2001, JT 2001, 610, AJT 2001-02, p. 495.

7 M. Bossuyt \& J. Wouters, Grondlijnen van internationaal recht, Antwerpen: Intersentia 2005, p. 425 e.v.

8 Zie hierover D. van Eeckhoutte, Bekendmaking van verdragen: voorstel tot genezing van een zieke, TVW 2002, p. 3-31.

9 In Nederland wordt aangenomen dat internationaal recht, waaronder ook de immuniteiten van internationale organisaties, automatisch geïncorporeerd is in de Nederlandse rechtsorde op basis van een ongeschreven grondwettelijke rechtsregel. Zie hierover L.F.M. Besselink \& R.A. Wessel, De invloed van ontwikkelingen in de internationale rechtsorde op de doorwerking naar Nederlands constitutioneel recht: een 'neo-monistische' benadering, Deventer: Kluwer 2009, p. 120.

10 P. Sands \& P. Klein, Bowett's Law of International Institutions, Londen: Sweet \& Maxwell 2009, p. 15-39. 
Administratief Tribunaal van de Internationale Arbeidsorganisatie dringt zorgplicht op aan Internationaal Strafhof: werkneemsters van het Strafhof mogen flexibel werken om borstvoeding te kunnen geven

judicial or legislative action. ${ }^{11}$ Dit wijst duidelijk in de richting van een volledige immuniteit.

Het nadeel van deze immuniteit is dat werknemers van internationale organisaties zich bij een - veelal arbeidsgerelateerd - geschil in beginsel niet tot een nationale rechter kunnen wenden om de door de administratie van de internationale organisatie genomen beslissing te betwisten. De kans is immers klein dat een nationale rechter de immuniteit naast zich neer zou leggen wanneer de verwerende internationale organisatie deze inroept. ${ }^{12}$

De nationale rechter zal enkel geneigd zijn de immuniteit van een internationale organisatie opzij te schuiven wanneer deze organisatie niet voorziet in een zogenoemde 'alternatieve rechtsgang'. Indien er echter een alternatieve rechtsgang beschikbaar is, weegt de immuniteit meer door dan het recht op een 'toegang tot de rechter' zoals dat in diverse juridische instrumenten vervat zit (onder andere artikel 6 Europees Verdrag voor de rechten van de mens (EVRM); artikel 14 Internationaal Verdrag inzake burgerrechten en politieke rechten). Vanuit mensenrechtelijk perspectief kan dit uiteraard problematisch zijn. Zo ontstaat er immers een spanningsveld tussen de immuniteit die de internationale organisatie geniet en de toegang tot een onpartijdige en onafhankelijke rechter wanneer een werknemer zijn rechten geschonden acht. Bovendien is het niet zo dat het louter voorhanden zijn van een 'alternatieve rechtsgang' daarom ook afdoende is om aan de waarborgen vervat in artikel 6 EVRM te voldoen. ${ }^{13}$ Dat dit kan leiden tot het toedekken van bepaalde misbruiken, niet in het minst bij arbeidsgeschillen, is ook de Raad van Europa als hoeder van het EVRM niet ontgaan. De Raad heeft zijn leden onlangs dan ook opgeroepen er op toe te zien dat de internationale organisaties waarvan zij lid zijn de fundamentele rechten naleven, en in het bijzonder artikel 6 EVRM. ${ }^{14}$

Een zestigtal internationale organisaties, waaronder alle organisaties die hiervoor werden opgelijst, heeft voor geschillen met hun werknemers in een alternatieve rechtsgang voorzien bij het Tribunaal in Genève. Dit Tribunaal is de opvolger van het Tribunaal van de Volkenbond, dat in eerste instantie enkel als taak had om geschillen met werknemers van de Internationale Arbeidsorganisatie (IAO) te beslechten. In 1949 werd tijdens de 32ste sessie van de Internationale Arbeidsconferentie besloten om ook andere internationale organisaties toe te laten tot het Tribunaal. Hiermee lijkt alvast te zijn voldaan aan de verplichtingen die voort-

11 Artikel 11 Zetelakkoord tussen het Internationaal Strafhof en het gastland (ICC-BD/04-01-08).

12 Hierbij in acht nemend dat de immuniteit in Nederland tot het gewoonterecht behoort, doch in België verankerd moet zijn in het verdrag (zie hiervoor).

13 Zie ook F. De Cock, Ook werknemer internationale organisatie heeft recht op garanties artikel 6 EVRM, De Juristenkrant 2017, 359, p. 12. Zie eveneens hierover (uitgebreid) M. Kullmann, Arbeidsrechtelijke geschillen en de immuniteit van internationale organisaties, TRA 2018, 5, p. 11-16. Naar aanleiding van twee arresten van de Nederlandse Hoge Raad van 20 januari 2017 (ECLI:NL:HR:2017:56 en ECLI:NL:HR:2017:57) hekelt Kullmann het feit dat de rechtspraak van het EHRM tot op heden geen ruimte lijkt te bieden om via het proportionaliteitsvereiste tot een inhoudelijke beoordeling van de alternatieve rechtsgang te komen in het licht van artikel 6 EVRM. De Hoge Raad volgde in beide zaken de rechtspraak van het EHRM.

14 Resolutie 2206 van de Raad van Europa (26 januari 2018), Jurisdictional immunity of international organisations and rights of their staff, http://assembly.coe.int. 
vloeien uit het EVRM inzake de organisatie van een alternatieve vorm van geschillenbeslechting. ${ }^{15}$

Het Tribunaal is samengesteld uit zeven rechters van verschillende nationaliteiten die benoemd worden voor een hernieuwbare periode van drie jaar. Normaliter komen zij twee- tot driemaal per jaar samen. Er worden per jaar om en bij de 150 uitspraken gedaan. ${ }^{16}$ Het Statuut van het Tribunaal voorziet erin dat deze zeven rechters allen van een verschillende nationaliteit moeten zijn. Hun aanstelling geldt voor een termijn van drie jaar en vindt plaats op voordracht van de Internationale Arbeidsconferentie, die het voorstel tot benoeming al dan niet aanneemt in een resolutie. Bij de behandeling van een zaak zijn normaliter drie rechters betrokken. In uitzonderlijke gevallen kan de voorzitter van het Tribunaal de samenstelling wijzigen naar vijf rechters, of in zeer uitzonderlijke gevallen naar alle zeven. ${ }^{17}$ Bij onenigheid beslissen de rechters bij meerderheid.

Een werknemer die zich in zijn rechten gekrenkt voelt, moet alle interne rechtsmiddelen uitputten alvorens hij zich tot het Tribunaal kan wenden. Deze vereiste is zowel opgenomen in de interne reglementering van de meeste internationale organisaties als in het Statuut van het Tribunaal. ${ }^{18}$

Het mag dan atypisch lijken dat een rechtsprekend orgaan zoals het Internationaal Strafhof zelf voor een - weliswaar administratief - internationaal tribunaal moet verschijnen, toch heeft het Tribunaal zich in de afgelopen tien jaar in wel dertig zaken tegen het Internationaal Strafhof uitgesproken in arbeidsrechtelijke geschillen. Het leeuwendeel van deze geschillen betreft het stopzetten (ontslag) of niet hernieuwen van de arbeidsrelatie bij tijdelijke contracten. ${ }^{19}$

De zaak die het voorwerp is van deze bespreking betreft een werkneemster van het Internationaal Strafhof die was uitgestuurd naar Kampala (Oeganda). Zij had tijdelijk flexibele werkomstandigheden gevraagd teneinde haar baby borstvoeding te kunnen geven. De administratie van het Strafhof weigerde dit. Na uitputting van de interne beroepsprocedure (zie hierna) was het aan het Tribunaal om zich over deze zaak te buigen.

15 Twee mijlpaalarresten in deze materie: EHRM 18 februari 1999, nr. 28934/95 (Beer \& Regan/ Duitsland) en EHRM 18 februari 1999, nr. 26083/94 (Waite \& Kennedy/Duitsland).

16 Zie www.ilo.org/tribunal. Hoewel de website melding maakt van twee sessies per jaar, worden momenteel meestal drie sessies gehouden om de achterstand in het aantal zaken niet te veel te laten oplopen.

17 Artikel III Statuut van het Administratief Tribunaal van de Internationale Arbeidsorganisatie.

18 Artikel VII(1) Statuut van het Administratief Tribunaal van de Internationale Arbeidsorganisatie; zie ook Sands \& Klein 2009, p. 426; voor de relevante bepaling bij het Strafhof, zie artikel 110.8 ICC Staff Rules.

19 ILOAT 28 juni 2017, nrs. 3857, 3858, 3860, 3862 en 3863; ILOAT 8 februari 2017, nr. 3728; ILOAT 6 juli 2016, nr. 3673; ILOAT 11 februari 2015, nrs. 3443 en 3444. 


\section{Omkadering: het belang van deze zaak}

De zaak A.L.G./International Criminal Court is interessant in verschillende opzichten. ${ }^{20}$

Om te beginnen heeft deze zaak interessante inhoudelijke aspecten. Het was de eerste keer dat het Tribunaal zich moest buigen over het specifieke geval van een werkneemster van een internationale organisatie die haar administratie vroeg om tijdelijk flexibele arbeidsvoorwaarden toegekend te krijgen, zodat zij haar kind borstvoeding kon geven. Ook bij andere administratieve tribunalen, zoals dat van de Verenigde Naties (UNAT/UNDT) en van de Raad van Europa (COE-AT), zijn er geen gelijkaardige zaken terug te vinden.

Bovendien bevat deze zaak ook enkele interessante procedurele elementen. Zo herbevestigt het Tribunaal wat het verstaat onder een 'beslissing' en gaat het met name in op de vraag of een 'mededeling' al dan niet een beslissing kan uitmaken. Daarnaast past het Tribunaal het principe van de dies a quo non computator toe (de termijn wordt gerekend vanaf de dag na de beslissing), en haalt het bovendien aan dat hierbij de reguliere werkdagen van de internationale organisatie in kwestie van belang zijn. Voor wat betreft de na te leven termijnen stelt het Tribunaal dat deze beginnen te lopen vanaf het moment dat de werknemer kennis kon nemen van de beslissing. In dit geval gaat het om een kennisgeving per e-mail.

\section{Feiten}

Verzoekster was een internationaal aangeworven werknemer bij het Internationaal Strafhof in Den Haag. Zulke werknemers kunnen - afhankelijk van hun jobomschrijving - gestationeerd worden in zogenoemde duty stations. Zo opereert het Strafhof onder meer vanuit de Centraal-Afrikaanse Republiek, Ivoorkust, de Democratische Republiek Congo, Kenia en Oeganda. Om tegemoet te komen aan de moeilijke en soms gevaarlijke werkomstandigheden voorziet het Strafhof in een eventuele bijkomende vergoeding voor werknemers die zich in zulke duty stations moeten vestigen. Hierbij wordt een classificatiesysteem gehanteerd dat op een schaal van A (laagste) tot E (hoogste) de moeilijkheid van de werkomstandigheden aanduidt. ${ }^{21}$ Naast dit classificatiesysteem van zogenoemde hardship wordt aan elk duty station ook de status family of non-family toegekend. Werknemers in een non-family-omgeving kunnen aanspraak maken op een extra toelage ter compensatie van het gebrek aan een normaal familieleven. ${ }^{22}$ De status non-family wordt toegekend indien de aanwezigheid van het gezin om veiligheidsredenen

20 Zie www.ilo.org/dyn/triblex/triblexmain.fullText?p_lang=en\&p_judgment_no=3861\&p_ language_code=EN.

21 In de categorie A wordt geen extra toelage betaald. Voor de andere categorieën geldt: B: tussen $\$ 5.810$ tot $\$ 8.140$ per jaar, C: tussen $\$ 10.470$ en $\$ 15.110$ per jaar, D: tussen $\$ 13.950$ en $\$ 18.590$ per jaar, E: tussen $\$ 17.440$ en $\$ 23.250$ per jaar (loonschaal van 1 juli 2016).

22 Deze toelage bedraagt $\$ 1.650$ per maand voor werknemers met personen ten laste, en $\$ 625$ per maand voor werknemers zonder personen ten laste (loonschaal van 1 juli 2016). 
niet mogelijk is voor een periode van zes maanden of langer. Minstens elke drie jaar wordt de inschaling voor elk duty station herzien.

Verzoekster was gestationeerd in het duty station van Kampala in Oeganda, dat de status family had. Zij diende zich echter vanuit Kampala op regelmatige basis naar non-family duty stations te begeven. In februari 2013 staakte zij deze verplaatsingen omwille van haar zwangerschap. Gelet op de gebrekkige medische voorzieningen in Kampala kon verzoekster tijdelijk (ongeveer vijf weken) werken vanuit Europa tot haar zwangerschapsverlof zou ingaan op 8 augustus 2013. Verzoekster schonk het leven aan een dochter op 11 augustus 2013.

Twee maanden later werd zij door de administratie van het Strafhof gecontacteerd in verband met de plannen voor haar terugkeer naar Kampala. Verzoekster gaf aan enkele tijdelijke flexibele arbeidsvoorwaarden met de administratie te willen bekijken omdat ze graag borstvoeding wilde geven. Daardoor zou ze in de onmogelijkheid zijn om zich naar non-family duty stations te begeven. Verzoekster gaf echter wel te kennen dat zij bereid was om zich naar landen te begeven waar haar dochter zou kunnen meereizen zodra haar zwangerschapsverlof ten einde was gekomen.

Op 4 november 2013 vernam zij van haar overste dat het Strafhof niet over een kader van tijdelijke flexibele arbeidsvoorwaarden beschikt. Bovendien werd zij er door haar overste aan herinnerd dat Kampala een family-status had, en dat zij aldus in principe haar dochter daarheen mee kon nemen. Op basis van de elementen die verzoekster had aangehaald en het feit dat zij ook non-family duty stations diende te frequenteren, veronderstelde haar overste dat verzoekster niet in de mogelijkheid was haar gewoonlijke arbeidsprestaties te leveren, waarop haar werd voorgesteld om gedurende deze periode onbetaald verlof te nemen. Verzoekster gaf te kennen dat dit haar duidelijk niet tot voordeel zou strekken en herhaalde haar verzoek om tijdelijk te telewerken.

Op 26 november 2013 informeerde de administratie verzoekster dat werknemers van het Strafhof geen recht hebben op telewerk. Bovendien herinnerde de administratie haar aan de richtlijnen die gelden bij het Strafhof betreffende het geven van borstvoeding. ${ }^{23}$

Verzoekster was van mening dat zij het slachtoffer was van discriminatie en intimidatie en verzocht de administratie haar standpunt betreffende telewerk en de toepassing van de richtlijnen omtrent het geven van borstvoeding te (her)bekijken. Zij voerde aan dat de richtlijnen in verband met borstvoeding in de veilige omgeving van Den Haag wellicht zonder veel problemen kunnen worden toegepast, doch dat dit voor duty stations in de mondiale periferie toch anders ligt.

In afwachting van het antwoord van de administratie nam verzoekster haar jaarlijkse betaald verlof op tot 10 januari 2014. Op 12 december 2013 stelde de administratie verzoekster in kennis dat, voor zover zij meer verlof wenste op te nemen dan waar zij jaarlijks recht op had, het nemen van bijzonder onbetaald verlof de 
enige mogelijkheid was voor haar. ${ }^{24}$ Op vraag van verzoekster werd aan haar - in navolging van het antwoord van de administratie van het Strafhof - bijzonder onbetaald verlof toegekend van 13 januari 2014 tot 11 augustus 2014 .

Op 12 januari 2014 vroeg verzoekster om de beslissing van 12 december 2013 te herzien. ${ }^{25}$ Dit is de eerste stap in de interne beroepsprocedure en die stap kan gezien worden als een soort willig beroep. De administratie, bij monde van de griffier van het Strafhof, informeerde verzoekster echter op 5 februari 2014 dat zij haar verzoek tot herziening niet tijdig had ingediend. De administratie hield voor dat de beslissing van 4 november 2013 had moeten worden aangevochten, en niet die van 12 december 2013. Op 10 maart 2014 diende verzoekster een beroep in bij de interne beroepscommissie, ${ }^{26}$ de tweede stap in de interne beroepsprocedure. Zij vermeldde dezelfde grieven als in haar verzoek tot herziening.

Verzoekster zette ondertussen haar arbeidsprestaties, na afloop van haar onbetaald verlof, weer verder in Kampala vanaf 12 augustus 2014.

De interne beroepscommissie kwam op 3 september 2014 met haar rapport. De klacht van verzoekster werd - in weerwil van het pleidooi van de administratie ontvankelijk verklaard, doch een meerderheid van de leden van de beroepscommissie vond deze ongegrond. Zij spoorden het Strafhof wel aan om de richtlijnen omtrent het geven van borstvoeding in een situatie als deze van verzoekster te verduidelijken. Eén lid van de beroepscommissie had een afwijkende mening en stelde dat het Strafhof de zorgplicht (duty of care) geschonden had.

Op 6 oktober 2014 meldde de administratie van het Strafhof aan verzoekster dat de nodige stappen zouden worden gezet om de problematiek rond de borstvoedingsrichtlijnen uit te klaren.

Volgend op de uitkomst - en uitputting - van alle facetten van de interne beroepsprocedure vroeg verzoekster op 30 december 2014 aan het Tribunaal om de beslissing van 12 december 2013 (zoals 'bevestigd' op 5 februari 2014 door de weigering de beslissing te herzien, en 'herbevestigd' op 6 oktober 2014 volgend op het rapport door de interne beroepscommissie) te verbreken en haar de gederfde inkomsten ten gevolge van het onbetaald verlof te vergoeden, ten belope van

24 Naaste het gewone betaalde verlof voorzien de Staff Rules van het Strafhof ook in bijzonder betaald of onbetaald verlof, en in een home leave om internationaal gerekruteerde medewerkers de kans te bieden banden met hun familie in hun thuisland te onderhouden. Het bijzonder onbetaald verlof kan worden aangevraagd voor: (1) studie/onderzoek; (2) verlengde ziekte; (3) zorgen voor kinderen; (4) verlengd moederschapsverlof, ouderschapsverlof of verlof bij adoptie; (5) het overlijden van een familielid; (6) een familiale noodtoestand; (7) om op het einde van de loopbaan de duur tot de pensioenleeftijd te overbruggen; (8) dwingende redenen. Het al dan niet toekennen van bijzonder betaald verlof is een volledig discretionaire bevoegdheid van de administratie en kan worden toegekend indien dit in het belang is van het Strafhof (zie artikel 105.2-4 ICC Staff Rules).

25 Conform artikel 111.1(c) van de Arbeidsvoorwaarden (staff regulations) van het Internationaal Strafhof en artikel 2 (b) van het reglement van de procedure bij de beroepscommissie (rules of procedure of the Appeals Board).

26 Conform artikel 111.1(d) van de Arbeidsvoorwaarden (staff regulations) van het Internationaal Strafhof en artikelen 2 (a) \& 4 (b) van het reglement van de procedure bij de beroepscommissie (rules of procedure of the Appeals Board). 
$€$ 38.132. Voor de geleden morele schade vroeg verzoekster een symbolische schadevergoeding van $€ 1$, alsook een compensatie voor de gemaakte kosten van $€ 6.000$. Het Strafhof daarentegen vroeg om de klacht ratione temporis als onontvankelijk te beschouwen, en in ondergeschikte orde als ongegrond.

\section{Procedure voor het Tribunaal}

\section{Procedurele gronden}

Het Internationaal Strafhof voerde aan dat de klacht van verzoekster bij het Tribunaal onontvankelijk was ratione temporis. De cruciale bepaling is artikel VII van het Statuut dat de werking van het Tribunaal vastlegt en duidelijk voorziet dat enkel de finale administratieve beslissing kan worden betwist, en dit binnen de 90 dagen nadat alle interne beroepsmechanismen werden uitgeput.

De discussie betrof evenwel niet de vraag of het beroep dat verzoekster bij het Tribunaal indiende op 30 december 2014 tijdig kwam. Het uitgangspunt lijkt hier te zijn dat de termijn van 90 dagen werd gerespecteerd. Het Internationaal Strafhof baseerde zijn stelling van laattijdigheid andermaal op de bewering dat verzoekster, in het kader van de interne procedure, reeds laattijdig was geweest. Volgens het Strafhof was zijn betwiste administratieve eindbeslissing immers te vinden in de mededeling van de overste van verzoekster van 4 november 2013 (zie hiervoor). De mededeling (per e-mail) van 12 december 2013 aan verzoekster zou niks meer zijn geweest dan een bevestiging hiervan. ${ }^{27}$ Volgens de regels betreffende de interne beroepsprocedure tegen administratieve beslissingen van het Internationaal Strafhof moet een 'verzoek tot herziening' binnen de 30 dagen worden ingediend. Het verzoek kwam, aldus het Strafhof, in elk geval te laat.

De verzoekster was echter, net zoals in de interne procedure, van mening dat noch de mededeling van haar overste van 4 november 2013, noch de informatie aan haar verstrekt op 26 november 2013 een finale administratieve beslissing uitmaakte. Zij stelde dat enkel de mededeling van 12 december 2013 haar volledig informeerde, en dat deze dus de finale administratieve beslissing was die vatbaar was voor een 'verzoek tot herziening' binnen de 30 dagen.

Om na te gaan of de procedure voor het Tribunaal ontvankelijk was, bestudeerde het Tribunaal de aard van elke communicatie tussen verzoekster en het Strafhof. $^{28}$

Hierbij heeft het Tribunaal gesteld dat enkel een beslissing die rechtsgevolgen doet ontstaan ten aanzien van verzoekster als een finale administratieve beslissing kan worden aangezien. ${ }^{29}$ In die zin oordeelde het Tribunaal dat de finale beslissing van het Strafhof gevonden moet worden in de kennisgeving van 12 december 2013 (zie hiervoor). ${ }^{30}$ Deze kennisgeving was immers de eerste die

ILOAT 28 juni 2017, nr. 3861 (A.L.G./International Criminal Court), overweging 1. ILOAT 28 juni 2017, nr. 3861 (A.L.G./International Criminal Court), overweging 3.

ILOAT 28 juni 2017, nr. 3861 (A.L.G./International Criminal Court), overweging 5. Zie eveneens ILOAT 4 juli 2012, nr. 3141 (I.T./World Health Organization) en ILOAT 18 november 1982, nr. 532 (Devisme/European Patent Organisation).

30 ILOAT 28 juni 2017, nr. 3861 (A.L.G./International Criminal Court), overweging 2. 
volledig was en ook verwees naar de mogelijkheid om een herziening te vragen. Het Tribunaal haalde bovendien ook aan dat indien er geen indicatie is dat een mededeling van de administratie een finale beslissing uitmaakt, de werknemer er redelijkerwijze van uit mag gaan dat dit niet het geval is. ${ }^{31}$ Hiermee nam het Tribunaal in feite hetzelfde standpunt in als de interne beroepscommissie van het Internationaal Strafhof.

Gelet op de voormelde termijn van 30 dagen voor het indienen van een verzoek tot herziening zou verzoekster - met toepassing van het beginsel dies a quo non computator - tot zaterdag 11 januari 2014 de tijd hebben gehad om haar verzoek in te dienen. Verzoekster diende dit echter pas op 12 januari 2014 in. Het Tribunaal merkte hierover op dat het reeds eerder oordeelde, in het kader van een interne beroepsprocedure, dat een termijn die vervalt op een zaterdag wordt verlengd tot de eerstvolgende reguliere werkdag wanneer de zaterdag geen reguliere werkdag is binnen de betrokken organisatie. ${ }^{32}$ Aangezien het Strafhof een werkweek hanteert van maandag tot vrijdag, diende de termijn te worden verlengd. ${ }^{33}$ Aldus oordeelde het Tribunaal dat het verzoek tot herziening tijdig werd ingediend in het kader van de interne procedure, en dat bijgevolg ook de klacht bij het Tribunaal ontvankelijk was ratione temporis. ${ }^{34}$

De claim van het Internationaal Strafhof dat verzoekster haar toegang tot het Tribunaal zou hebben verloren (wat hier uiteindelijk dus niet het geval bleek), is op zijn minst bizar te noemen. Dat is in de eerste plaats zo omdat het Strafhof helemaal geen elementen had aangehaald waarom de interne beroepscommissie zich wat betreft de ontvankelijkheid ratione temporis zou hebben vergist. ${ }^{35}$ Het feit dat de interne beroepscommissie de vordering ten gronde heeft behandeld, impliceert dat de vordering ontvankelijk was. Het is dus des te opmerkelijker dat het Strafhof in de procedure voor het Tribunaal opnieuw uit hetzelfde vaatje tapt en in feite zijn eigen interne beroepscommissie terechtwijst. Volgend op de beslissing van de administratie van 6 oktober 2014, die op basis van het rapport van de beroepscommissie haar standpunt niet wijzigde en waarmee alle interne beroepsprocedures waren uitgeput, heeft verzoekster haar zaak dan uiteindelijk voor het Tribunaal gebracht.

\section{Materiële gronden}

Verzoekster haalde in haar vordering voor het Tribunaal verschillende argumenten ten gronde aan. Zo zou het Strafhof niet zijn ingegaan op het door haar voorgestelde alternatief voor de weigering van telewerk (een gedetailleerde beschrijving van deze feiten ontbreekt in de beslissing van het Tribunaal), en zou zij

31 In diezelfde zin zie ILOAT 11 juli 2007, nr. 2644 (A.Z./United Nations Industrial Development Organization).

32 ILOAT 28 juni 2017, nr. 3861 (A.L.G./International Criminal Court), overweging 6.

33 Het Internationaal Strafhof heeft in 2007 de officiële werktijden vastgelegd en de werkweek gedefinieerd als lopende van maandag tot en met vrijdag, zie International Criminal Court, Official Working Hours of the Court and Official Holidays (ICC/HRS/2007/7229); ILOAT 8 juli 2009, nr. 2831 (S.G.G./World Intellectual Property Organization).

34 ILOAT 28 juni 2017, nr. 3861 (A.L.G./International Criminal Court), overweging 6 in fine.

35 ILOAT 28 juni 2017, nr. 3861 (A.L.G./International Criminal Court), overweging 7. 
slachtoffer zijn geweest van discriminatie op basis van geslacht. Het Tribunaal is echter enkel ingegaan op de stelling van verzoekster dat het Strafhof zijn zorgplicht (duty of care) zou hebben geschonden. ${ }^{36}$

Met betrekking tot de schending van de zorgplicht haalde verzoekster aan dat het niet duidelijk is hoe de richtlijn inzake het geven van borstvoeding getransponeerd kan worden op werknemers die zich met regelmaat naar duty stations moeten begeven, en meer bepaald de non-family duty stations. Verzoekster was van mening dat er een plicht rust op de administratie van het Strafhof om zulke richtlijn te ontwikkelen, of bij gebrek hieraan de regels en praktijken toe te passen zoals die gelden bij (andere) agentschappen van de Verenigde Naties. ${ }^{37}$

Daar gelden namelijk richtlijnen van 2003 die de werkneemster een dagelijkse reductie van de arbeidstijd toestaan om borstvoeding te geven of melk af te kolven. Voor werknemers die naar family duty stations moeten reizen, is voorzien dat het kind mee mag reizen. Deze richtlijnen laten werknemers die naar non-family duty stations moeten reizen echter opnieuw buiten beschouwing.

Het Tribunaal vestigde er de aandacht op dat het principe van goede trouw (good faith) en hiermee samenhangend de zorgplicht (duty of care) internationale organisaties ertoe moet aanzetten om hun werknemers met de nodige aandacht te behandelen teneinde hen onnodig leed te besparen. ${ }^{38}$ Deze stelling van het Tribunaal berust op vaste rechtspraak. ${ }^{39}$ Bovendien is de administratie van de internationale organisatie ertoe gehouden om een werknemer voldoende te informeren wanneer een te nemen beslissing zijn rechten in gevaar zou kunnen brengen. ${ }^{40}$

In dit geval was het Tribunaal van mening dat de weigering van het Strafhof om verzoekster in haar hoedanigheid van borstvoeding gevende werkneemster tijdelijke flexibele arbeidsvoorwaarden toe te staan, in strijd is met de eerder aangehaalde principes. ${ }^{41}$

Zo meende het Tribunaal dat er voldoende elementen aanwezig waren in het dossier om aan te nemen dat een tegemoetkoming aan de vraag van verzoekster om tijdelijk te kunnen telewerken niet geheel onmogelijk zou zijn geweest. Bovendien, zo merkte het Tribunaal op, was het ook perfect mogelijk geweest om verzoekster te laten werken in Kampala zonder van haar te verwachten dat ze zich naar non-family duty stations zou begeven. In dit verband verwees het Tribunaal naar het feit dat het Strafhof deze maatregel toeliet toen verzoekster in 2014 opnieuw zwanger was. ${ }^{42}$ 
Het Tribunaal stelde verzoekster in het gelijk, met inwilliging van haar volledige vordering, met name de omzetting van onbetaald verlof naar bijzonder betaald verlof (met de volledige uitbetaling van de gederfde inkomsten), de uitbetaling van $€ 1$ morele schadevergoeding en een tegemoetkoming van $€ 6.000$ in de kosten. ${ }^{43}$

\section{Commentaar}

\section{Procedureel}

Hoewel een uitgebreide analyse van de interne (binnen de internationale organisatie) en externe (bij het Tribunaal) rechtsgang het bestek van deze annotatie te buiten gaat, zijn enkele bedenkingen hier toch op hun plaats.

Op de staten die het EVRM hebben onderschreven als lid van de Raad van Europa, en tevens lid zijn van tal van andere internationale organisaties, rust de verplichting om de mensenrechten, zoals opgenomen in het EVRM, te respecteren. De Raad van Europa heeft, zoals hiervoor reeds vermeld, onlangs een resolutie uitgevaardigd om zijn leden ertoe aan te zetten nauw toe te zien op de naleving van mensenrechtelijke aspecten binnen internationale organisaties waarvan zij lid zijn. In deze resolutie wordt artikel 6 EVRM (recht op een eerlijk proces) uitdrukkelijk vermeld. Nochtans kan de verenigbaarheid met artikel 6 van de interne en externe rechtsgang bij het Strafhof op verschillende vlakken in vraag worden gesteld.

In de eerste plaats is de interne beroepscommissie onpaar samengesteld, met twee vertegenwoordigers van de administratie en slechts één vertegenwoordiger van het personeel. Dat doet op zijn minst de wenkbrauwen fronsen. Het is nog maar de vraag of in dergelijk geval wel sprake kan zijn van een onafhankelijke instantie in de zin van artikel 6 EVRM.

De tweede bedenking houdt verband met het feit dat, bovenop de reeds genoemde vereiste dat alle interne beroepsprocedures uitgeput moeten zijn alvorens het Tribunaal kan worden gevat, ${ }^{44}$ het Tribunaal ook steevast vooropstelt dat enkel een beslissing die rechtsgevolgen doet ontstaan als een administratieve beslissing kan worden beschouwd waartegen beroep openstaat. ${ }^{45}$ Vanuit dit perspectief zou het de rechtspositie van werknemers bij internationale organisaties ten goede komen indien administraties van internationale organisaties in hun

43 ILOAT 28 juni 2017, nr. 3861 (A.L.G./International Criminal Court), overweging 11 en 12.

44 Artikel VII(1) Statuut van het Administratief Tribunaal van de Internationale Arbeidsorganisatie.

45 ILOAT 13 september 1960, nr. 45 (Kahal/World Health Organization): Wanneer een werknemer louter over iets wordt geïnformeerd zonder dat dit voor de werknemer rechtsgevolgen creëert, is een vordering voor het Tribunaal onontvankelijk. ILOAT 10 april 1965, nr. 85 (Jurado/International Labour Organization): Omgekeerd is het ook zo dat wanneer een internationale organisatie een beslissing intrekt, het Tribunaal niet meer kan worden gevat. De rechtsgevolgen die met die beslissing voor de werknemer werden gecreëerd, hebben dan immers geen uitwerking meer. De kennisgeving waarmee de beslissing die rechtsgevolgen deed ontstaan werd ingetrokken, kan niet worden beschouwd als een (nieuwe) beslissing waarvoor een procedure bij het Tribunaal open staat. De werknemer bevindt zich dan immers niet meer in een ongunstiger situatie dan wanneer de beslissing uitwerking had. 
beslissingen zouden aangeven welke interne en externe beroepsmogelijkheden voorhanden zijn. Vele nationale rechtsordes leggen een dergelijke verplichting al op in een wet 'openbaarheid van bestuur'. Ten aanzien van individuele administratieve beslissingen beginnen de termijnen dan ook maar te lopen van zodra de rechtsonderhorige kennis krijgt van de beroepsmogelijkheden. Een dergelijke aanpak ontbreekt momenteel totaal bij de internationale organisaties.

Een derde bedenking betreft de termijnen, en ook hier is de link met artikel 6 EVRM in feite niet veraf. Zoals hiervoor reeds aangehaald, oordeelde het Tribunaal dat het verzoek tot herziening van 12 januari 2014 tegen de beslissing van 12 december 2013 tijdig werd ingediend omwille van een verlenging van de 30dagentermijn tot de eerstvolgende werkdag. De beslissing volgend op dit verzoek tot herziening werd door de administratie kenbaar gemaakt op 5 februari 2014 en stelde, zoals eerder reeds aangehaald, dat het niet tijdig was. Het beroep tegen deze beslissing van 5 februari 2014 werd pas 32 dagen later bij de interne beroepscommissie ingediend, met name op 10 maart 2014. Nochtans gold hier opnieuw een termijn van 30 dagen. ${ }^{46}$ Aangezien de termijn deze keer verliep op een vrijdag, kon deze in beginsel niet verlengd worden. Nochtans heeft de interne beroepscommissie een rapport opgemaakt en de materiële feiten van de hand gewezen, waardoor zij de klacht impliciet ontvankelijk verklaarde.

Het heeft er alle schijn van dat de interne beroepscommissie van het Strafhof zich hier mild opstelde ten aanzien van verzoekster. Uit het dossier blijkt immers dat verzoekster met vakantie was in de betrokken periode, en dat er dus een kans is dat de beslissing haar pas later heeft bereikt. Dit is in overeenstemming met eerdere rechtspraak van het Tribunaal. Dit stelde reeds vroeg in zijn bestaansgeschiedenis dat er een verschil moet worden gemaakt tussen de datum waarop een beslissing door de administratie werd genomen en de datum waarop deze aan de werknemer werd kenbaar gemaakt. ${ }^{47}$ Het bewijs hiervan moet geleverd worden door de verwerende organisatie. ${ }^{48}$ Indien de verwerende organisatie daar niet in slaagt, wordt de datum die de verzoeker aanhaalt doorgaans aanvaard. Dit hoeft niet echt te verbazen. Vooral e-mail is een vaak gebruikt communicatiemiddel binnen het Strafhof. Gelet op de afstand tussen de hoofdzetel van het Strafhof in Den Haag en de duty stations in onder meer Kampala is dit wellicht de meest efficiënte communicatiewijze. Het moment waarop de e-mail wordt gelezen (en traceerbaar is binnen het webmailsysteem van het Strafhof), wordt door de administratie gezien als het moment waarop kennis wordt genomen van de inhoud, ${ }^{49}$ en bijgevolg als start voor de 30-dagentermijn.

De toepassing van dit - ongetwijfeld goedbedoelde - principe vergt nochtans enige voorzichtigheid. Dat is duidelijk gebleken uit een andere zaak die door het

Artikel (b) i van het reglement van de procedure bij de beroepscommissie (rules of procedure of the Appeals Board).

47 ILOAT 6 oktober 1961, nr. 54 (Van der Ploeg/United Nations Educational, Scientific and Cultural Organization).

48 ILOAT 14 mei 1981, nr. 447 (Quiñones/Pan American Health Organization), recent aangehaald in ILOAT 28 juni 2017, nr. 3838 (F.S./United Nations Educational, Scientific and Cultural Organization). 
Tribunaal werd behandeld. Gelet op de onbetrouwbaarheid van de internetverbinding in de duty stations is het gebruikelijk om ook in het hoofdkantoor in Den Haag een werknemer van dezelfde dienst toegang te geven tot de e-mailaccount van elke werknemer in een duty station. Op die wijze kunnen dringende berichten toch behandeld worden en desnoods telefonisch aan de werknemer in het duty station doorgegeven worden. Dit kan uiteraard tot problemen leiden wanneer een administratieve beslissing aldus als gelezen wordt beschouwd op het moment dat deze gelezen wordt door een collega van de bestemmeling.

\section{Materieel}

De VN poneerden in 2016 nog dat het geven van borstvoeding een kwestie van mensenrechten uitmaakt. ${ }^{50}$ Borstvoeding wordt in verband gebracht met onder meer het recht op leven, het recht op ontwikkeling en het recht op gezondheid. Het is een kwestie van kinderrechten, maar ook van vrouwenrechten. Ook in de rechtsleer wordt borstvoeding, alsook het accommoderen van borstvoeding in een arbeidsgerelateerde context, gelinkt aan de rechten van het kind en de rechten van werkende vrouwen. ${ }^{51}$ Voor wat de rechten van werkende vrouwen betreft, is er uiteraard de connectie met de bescherming van de veiligheid en gezondheid van de werkende moeder en haar jonge kind. In dit verband worden van de overheid actieve beschermingsmaatregelen verwacht, zoals bijvoorbeeld de verplichting voor werkgevers om borstvoedingspauzes toe te kennen, en te vermijden dat werkneemsters die borstvoeding geven in contact komen met chemische agentia. Anderzijds resulteert de link met de rechten van werkende vrouwen ook in een noodzaak aan maatregelen die discriminatie op grond van borstvoeding aanpakken. Dit zijn dan eerder passieve beschermingsmaatregelen die vereisen dat werkgevers borstvoeding en de bescherming die op grond van deze borstvoeding wordt verleend niet aangrijpen als een reden om vrouwen te benadelen.

De analyse van het Tribunaal in de hier besproken zaak is eigenlijk volledig opgehangen aan passieve beschermingsmaatregelen, en dit omwille van het feit dat het Strafhof, eigenaardig genoeg, aan geen enkele actieve verplichting is onderworpen om werkneemsters zoals verzoekster, die regelmatig naar non-family duty stations moeten reizen, enigszins tegemoet te komen in de periode waarin ze borstvoeding geven. Deze groep werkneemsters wordt immers niet beoogd door de interne richtlijnen inzake het geven van borstvoeding. Of specifieke internationale instrumenten, zoals deze van de IAO, hier een oplossing kunnen bieden, is nog maar de vraag. Deze instrumenten leggen dan wel verplichtingen op aan de onderschrijvende staten, maar niet aan internationale organisaties die geen partij zijn bij zulke instrumenten.

50 Joint statement by the UN Special Rapporteurs on the Right to Food, Right to Health, the Working Group on Discrimination against Women in law and in practice, and the Committee on the Rights of the Child in support of increased efforts to promote, support and protect breastfeeding, beschikbaar op www.ohchr.org (consultatie 2 maart 2018).

51 Zie bijvoorbeeld K. Alidadi, Oog op de klok, deurknop in de hand: borstvoedingspauze voor werkende moeders tussen accommodatiegedachte en barrièrevorming, TSR 2012, 1, p. 35-102. 
De IAO ontwikkelde aangaande de bescherming van het moederschap, waaronder ook borstvoeding dient te worden begrepen, de Conventie nr. $\mathrm{C}_{18} 3^{52}$ en Aanbeveling nr. R191. ${ }^{53}$ Het is op het eerste gezicht enigszins bizar dat verzoekster deze instrumenten niet zelf in het debat heeft betrokken. In de zaak van verzoekster is met name artikel 3 van de Conventie betreffende de bescherming van het moederschap relevant: daarin zit immers de verplichting vervat om in overleg met de representatieve organisaties van werknemers en werkgevers afdoende maatregelen te nemen, zodat zwangere of borstvoeding gevende vrouwen niet verplicht worden om werk te verrichten dat de gezondheid van moeder en kind in het gedrang brengt. Dit geldt eveneens wanneer hier een wezenlijk risico toe bestaat. Ook artikel 10 van deze Conventie is van belang. Dit verwoordt het recht op een vermindering van werkuren en het recht op pauzes om borstvoeding te kunnen geven. Zowel deze vermindering van de arbeidsduur als eventuele pauzes mogen geen impact hebben op de verloning.

De reden waarom het Tribunaal deze instrumenten niet zelf heeft aangehaald, houdt - zoals hiervoor reeds werd opgemerkt - wellicht verband met het feit dat internationale organisaties, zoals het Internationaal Strafhof, geen partij zijn bij deze instrumenten. Het Tribunaal is tot nader order steeds zeer duidelijk geweest: '[D]eze instrumenten [conventies] creëren verplichtingen ten aanzien van de lidstaten en zijn niet van toepassing tussen de [internationale organisatie] en hun werknemers. ${ }^{54}$ Een wijziging aan het Statuut van het Tribunaal dat het de aanbevelingen en conventies uit eigen stal mee kan betrekken in de besluitvorming zou soelaas kunnen brengen, doch is vooralsnog niet aan de orde.

Een vergelijkbare paradox lijkt binnen de rechtsorde van de Europese Unie een andere oplossing te hebben gekregen. Aan het Hof van Justitie van de Europese Unie werd immers de vraag voorgelegd of de instrumenten van Unierecht die betrekking hebben op arbeid eveneens van toepassing moeten worden verklaard op de werknemers bij de Europese Unie zelf. Deze vraag werd uiteindelijk, alvast voor wat betreft het recht op jaarlijkse vakantie, op bevestigende wijze beantwoord. ${ }^{55}$

Toch moet opgemerkt worden dat het Tribunaal in het verleden heeft aangetoond dat het wel degelijk creatief kan zijn. Onlangs nog oordeelde het Tribunaal ${ }^{56}$ in verband met een door een verzoeker ingeroepen schending van IAO-Conventie

52 Conventie van de Internationale Arbeidsorganisatie nr. 183 betreffende de herziening van de bescherming van het moederschap (2000), geratificeerd door 34 landen.

53 Aanbeveling van de Internationale Arbeidsorganisatie nr. 191 betreffende de bescherming van het moederschap (2000).

54 ILOAT 8 februari 2017, nr. 3726 (I.R./International Organization for Migration).

55 HvJ EU 19 september 2013, C-579/12 RX-II, ECLI:EU:C:2013:570. Voor een bespreking: zie A. de Becker, Overdracht van jaarlijkse vakantie bij ziekte: alle ambtenaren zijn gelijk, zelfs EU-ambtenaren zijn niet langer (on)gelijker dan de ambtenaren van de lidstaten, ArA 2014, 3, p. 81-98.

56 ILOAT 8 februari 2017, nr. 3726 (I.R./International Organization for Migration): Zo stelde verzoekster dat zij door haar werkgever uitgebuit werd doordat zij allerhande taken toegewezen kreeg die niet in overeenstemming waren met haar loonschaal. 
nr. C29 (betreffende dwangarbeid) ${ }^{57}$ dat deze in beginsel niet van toepassing is, ${ }^{58}$ doch dat de aangehaalde schending niet enkel een beginsel uit de ingeroepen conventie betrof, maar eveneens een beginsel vervat in de Verklaring betreffende de fundamentele principes en rechten op het werk. ${ }^{59}$ Op basis van het enkele feit dat het Tribunaal niet enkel de interne regelgeving van de betrokken internationale organisatie toepast, maar eveneens algemene rechtsbeginselen en mensenrechten, werden de principes vervat in de Conventie toch meegenomen in de besluitvorming. ${ }^{60}$

Men kan zich afvragen of een redenering als de voorgaande het Tribunaal in de hier besproken zaak niet in de mogelijkheid had kunnen brengen om in te gaan op de stelling van verzoekster dat zij werd gediscrimineerd op basis van geslacht. Het staat immers buiten kijf dat verzoekster enkel en alleen omwille van het geven van borstvoeding verplicht werd om onbetaald verlof op te nemen. Aangezien enkel vrouwen borstvoeding kunnen geven, lijkt het niet zeer vergezocht te stellen dat hier sprake was van discriminatie, en dit minstens op indirecte wijze. ${ }^{61}$ En laat het uitbannen van alle discriminatie in het kader van arbeid en tewerkstelling nu precies een van de vier pijlers van de hiervoor vermelde Verklaring betreffende de fundamentele principes en rechten op het werk zijn.

Het Tribunaal heeft er echter voor gekozen om niet met de passieve beschermingsmaatregel van het discriminatieverbod te werken, maar met de minder voor de hand liggende zorgplicht, die door verzoekster slechts in laatste instantie werd aangehaald.

De zorgplicht kan worden gedefinieerd als de verplichting van een werkgever om met de nodige zorg te waken over het welzijn van zijn werknemers. ${ }^{62}$ Opdat er sprake zou zijn van een schending van de zorgplicht moet aan volgende criteria zijn voldaan: (1) de schade ten aanzien van diegene die zich op de zorgplicht beroept, moet voorzienbaar zijn; (2) diegene die zich op het beginsel beroept, moet een nauwe band hebben met diegene van wie de zorg mag worden verwacht; en (3) het inroepen van een schending van de zorgplicht is redelijk en valt te rechtvaardigen. ${ }^{63}$

Deze voorwaarden lijken hier vervuld: (1) het was voor het Strafhof voorzienbaar dat het niet toekennen van tijdelijke flexibele arbeidsvoorwaarden (met als enige

57 Conventie van de Internationale Arbeidsorganisatie nr. 29 betreffende het verbod op dwangarbeid (1930).

58 In dezelfde zin zie ILOAT 11 juli 2007, nr. 2662 (A.G.S./United Nations Industrial Development Organization).

59 Verklaring van de IAO betreffende de fundamentele principes en rechten op het werk (1998).

60 ILOAT 31 januari 1994, nr. 1333 (Franks/European Patent Organisation).

61 Zie in die zin bijvoorbeeld ook: Alidadi 2012, p. 97-101.

62 Zie hierover o.m. F. Dorssemont, Omtrent de mogelijkheidsvoorwaarden, de grondslagen, de beperkingen, de demonen, de gevaren en de voordelen van de institutionele leer, casu quo de institutionele leerstelsels, TPR 2003, 4, p. 1379-1380 en de voetnoten aldaar.

63 Zie hierover onder meer S.H. Bailey, Cases, Materials and Commentary on Administrative Law, Londen: Sweet \& Maxwell 2005, p. 1046 e.v.; P. Gillies, Business Law, Sydney: Federation Press 2004, p. 70 e.v.; P. Chandler, Waud's Employment Law: the Practical Guide for Personnel Managers, Trade Union Officials; Employers, Employees and Lawyers, Londen: Kogan Page 2003, p. 408 e.v. 
alternatief bijzonder onbetaald verlof) schade - in de ruime zin van het woord - bij verzoekster teweeg zou brengen; (2) ook wat betreft de nauwe band kan gesteld worden dat een arbeidsrelatie van die aard is dat deze daaronder kan gecatalogeerd worden; en (3) ten slotte zijn er ook argumenten om te stellen dat het inroepen van een schending van de zorgplicht in casu redelijk is. Men kan verzoekster namelijk niet verwijten dat zij zich moeilijk heeft opgesteld ten aanzien van haar werkgever. Zij deed bijvoorbeeld zelf een voorstel om naar Kampala terug te keren, zonder evenwel (tijdelijk) non-family duty stations te bezoeken, of om haar met een andere opdracht (in een ander land) te belasten waarbij haar baby zonder problemen kon meereizen.

Binnen de conventies van de IAO is het principe van zorgplicht, al dan niet impliciet, terug te vinden in Conventie nr. C155 betreffende Veiligheid en Gezondheid op het Werk van 1981 en Conventie nr. C187 betreffende een Aanbevelingskader voor Veiligheid en Gezondheid op het Werk van 2006. Maar zoals reeds aangehaald, kan het louter aanhalen van conventies het Tribunaal in principe niet overtuigen. In de arbeidsvoorwaarden van het Strafhof zelf kan ook artikel VI van de Staff Regulations worden aangehaald, dat stelt dat in een systeem van sociale zekerheid, inclusief bepalingen voor de bescherming van de gezondheid, in ziekteverlof, zwangerschapsverlof en een redelijke compensatie in geval van ziekte of ongeval zal worden voorzien. Dit kan dienen om een brug te slaan naar het zorgplichtprincipe, dat het Tribunaal in de hier besproken zaak toepaste. 
Administratief Tribunaal van de Internationale Arbeidsorganisatie dringt zorgplicht op aan Internationaal Strafhof: werkneemsters van het Strafhof mogen flexibel werken om borstvoeding te kunnen geven

Het Tribunaal past het zorgplichtprincipe reeds geruime tijd toe. ${ }^{64}$ In een uitspraak die reeds van 1980 dateert, lichtte het Tribunaal dit, in zekere mate binnen het toepassingsgebied van de hier besproken zaak, duidelijk toe: '[Het] is een fundamenteel principe binnen elke arbeidsrelatie dat de werkgever niet kan verwachten dat de werknemer dient te werken op een plaats waarvan die weet dat het onveilig is. ${ }^{65}$ Het lijdt geen twijfel dat de werkomstandigheden in duty stations zoals Kampala moeilijker zijn dan die in het hoofdkwartier van het Strafhof in Den Haag. Het ziet er op het eerste gezicht dan ook naar uit dat de richtlijnen die het Strafhof voor zijn werknemers hanteert as such niet kunnen worden toegepast voor werknemers die voor het Strafhof tewerkgesteld zijn in de mondiale periferie. Dit veiligheidscriterium moet flexibel kunnen worden ingevuld: voor een pas bevallen moeder die borstvoeding wenst te geven, mag de norm wellicht wat worden opgeschroefd.

64 Recente uitspraken hieromtrent van het Tribunaal: ILOAT 28 juni 2017, nr. 3878 (F.L./Food and Agriculture Organization of the United Nations: Er is geen schending van de zorgplicht indien de administratie een werknemer geen advies verstrekt voor het invullen van een belastingsaangifte. ILOAT 28 juni 2017, nr. 3845 (Y.K.A./African, Caribbean and Pacific Group of States): Een organisatie die tijdens de proefperiode een werknemer niet tijdig en duidelijk informeert over zijn prestaties schendt het principe van goede trouw en de zorgplicht. ILOAT 28 juni 2017, nr. 3840 (A.G./United Nations Industrial Development Organization): Een organisatie die een werknemer niet bijstaat om een beroep tegen haar in te dienen schendt de zorgplicht niet. ILOAT 6 juli 2016, nr. 3688 (E.P.M./World Health Organization): Een internationale organisatie schendt de zorgplicht wanneer zij enerzijds een werknemer ontslaat wegens stopzetting van een bepaalde taak, en anderzijds iemand anders rekruteert voor een taak waarvoor de ontslagen werknemer eveneens gekwalificeerd was om deze uit te voeren. ILOAT 30 juni 2015, nr. 3485 (A.M.E.F./International Criminal Court): Het feit dat de organisatie bepaalde aantijgingen van intimidatie door een werknemer onbeantwoord laat, toont een zekere mate van onverschilligheid aan, hetgeen een schending van de zorgplicht uitmaakt. ILOAT 11 februari 2015, nr. 3432 (B.M./European Patent Organization): Wanneer een organisatie een werknemer adviseert een bepaalde procedure te volgen waarvoor een makkelijker alternatief bestaat, dan schendt de organisatie de zorgplicht. ILOAT 11 februari 2015, nr. 3422 (M.F.A.A./Global Funds to Fight AIDS, Tuberculosis and Malaria): Een organisatie die op een grootschalig evenement publiekelijk een werknemer voorstelt als tijdelijk nieuw directeur zonder die daarover eerst in te lichten schendt de zorgplicht. ILOAT 11 februari 2015, nr. 3409 (G.V./International Fund for Agricultural Development): Een organisatie die de waardigheid van een werknemer niet respecteert wanneer zij de jobtitel van een werknemer aanpast die deze kan demotiveren, schendt de zorgplicht. ILOAT 9 juli 2014, nr. 3373: Een organisatie die beslist om bepaalde taken uit te besteden, schendt de zorgplicht indien niet in voldoende financiële compensatie wordt voorzien voor de werknemers die deze taak voordien uitoefenden en hiervoor steeds een bijzondere compensatie hadden ontvangen. ILOAT 9 juli 2014, nr. 3336 (G.J.K./European Organisation for the Safety of Air Navigation,L.E.R./European Patent Organisation): Een organisatie die het nemen van een beslissing 3,5 jaar laat aanslepen schendt de zorgplicht. ILOAT 6 februari 2013, nr. 3189 (G.R. et al./European Organization for the Safety of Air Navigation): De zorgplicht omvat niet de plicht om de regelgeving steeds ten voordele van de werknemer te interpreteren. ILOAT 4 juli 2012, nr. 3127 (V.C./Centre fort he Development of Enterprise): Een organisatie schendt de zorgplicht wanneer ze een werknemer, die weliswaar binnen de vooropgestelde termijnen een beroep bij de administratie heeft ingediend, niet de kans biedt om aan bepaalde formele vormvereisten te voldoen. ILOAT 8 februari 2012, nr. 3104 (G.C./ International Atomic Agency): Een organisatie schendt de zorgplicht indien ze een werknemer die na ziekte terug komt werken onvoldoende werk verschaft, waardoor deze zich overbodig voelt. 


\section{Conclusie}

De hier besproken uitspraak van het Tribunaal illustreert dat de rechtspositie van werknemers bij internationale organisaties verschillende knelpunten bevat. Een en ander valt te verklaren door het feit dat de rechten waar werknemers aanspraak op kunnen maken, moeten worden gevonden binnen het juridisch kader van de internationale organisatie zelf. Daar waar er een juridisch vacuüm bestaat, beschikt de administratie over verregaande bevoegdheden om zelf beslissingen te nemen. Dit veroorzaakt veel onduidelijkheid. De vraag welke rechtsbronnen het Tribunaal kan toepassen in het geval van een geschil, bevindt zich al evenzeer in een schemerzone. Het Statuut van het Tribunaal houdt het in beginsel op de staff regulations van de organisatie waartegen een zaak aanhangig wordt gemaakt. ${ }^{66}$ Het Tribunaal staat eerder negatief tegenover een analoge toepassing van gewoonlijke praktijken van een andere organisatie, ${ }^{67}$ ook al zou dit soms wenselijk kunnen zijn. ${ }^{68}$

Een eerste knelpunt dat de hier besproken zaak blootlegt, bevindt zich op het procedurele vlak. Daar blijkt wel wat marge te bestaan voor een verbetering van het geschillenbeslechtingsmechanisme waaraan werknemers van een internationale organisatie zijn onderworpen. Zoals aangegeven in deze bespreking, is met name de verenigbaarheid van de rechtspositie van werknemers van het Strafhof met artikel 6 EVRM (recht op een eerlijk proces) twijfelachtig.

Het tweede knelpunt dat deze uitspraak illustreert, bevindt zich op het materieelrechtelijke vlak, en met name de loutere verwijzing naar het juridisch kader van de internationale organisatie zelf voor het bepalen van alle rechten en plichten van de werknemers van de internationale organisaties.

Hoewel de remedie die het Tribunaal aan verzoekster biedt voor wat betreft het borstvoedingsverlof enigszins genoegdoening geeft, ware het interessant geweest indien het Tribunaal wat uitgebreider zou zijn geweest in zijn overwegingen inzake het gebrek aan enige regeling voor pas bevallen werkneemsters die aan de slag zijn in non-family duty stations.

Dat het Tribunaal met name het argument van een discriminatie op grond van geslacht onbeantwoord laat, valt in die zin te betreuren. Zoals hiervoor reeds gemeld, kan relatief gemakkelijk worden aangevoerd dat hier sprake is van een discriminatie op grond van geslacht, gelet op het feit dat enkel vrouwen zich gedwongen kunnen weten om onbetaald verlof op te nemen omwille van borstvoeding. Hierin kan men vrij eenvoudig een toepassing herkennen van het verbod op discriminatie op grond van geslacht in de arbeidssfeer, zoals dat is opgenomen in tal van grondrechtenverdragen, en niet in het minst in de Conventies van de IAO. Het inroepen van internationale verdragen blijkt echter moeilijk te liggen in procedures voor het Tribunaal, zoals ook hier weer is gebleken. Dat het Tribunaal meer heil zag in het weerhouden van een schending van de zorgplicht stelt verzoekster dan wel in het gelijk, maar geeft blijk van een enigszins administratieve 
benadering van het dispuut ten gronde. Het geven van borstvoeding koppelen aan de mensenrechten zou alvast van meer durf hebben getuigd.

Gelet op de missie van de IAO - samengevat: het promoten van sociale gerechtigheid en internationaal erkende mensenrechten en werknemersrechten - zou het Tribunaal van diezelfde IAO er goed aan doen om in zijn statuut op te nemen dat de internationale organisaties die de jurisdictie van het Tribunaal erkennen zich eveneens dienen te onderwerpen aan de conventies en aanbevelingen die de IAO zo sterk promoot: patere legem quem ipse fecisti. Op korte termijn is er misschien reeds een opening gemaakt in de richting van de fundamentele IAO-conventies door de recente rechtspraak van het Tribunaal (zie hiervoor) die aangeeft dat er zogenoemde algemene rechtsbeginselen en mensenrechten worden meegenomen in de besluitvorming van het Tribunaal. Voor een Tribunaal dat onder auspiciën van de IAO opereert, is dat wellicht het minimum dat men kan verwachten. 